ISSN 1392-3196 / e-ISSN 2335-8947

Zemdirbyste-Agriculture, vol. 103, No. 1 (2016), p. 61-66

DOI $10.13080 / \mathrm{z}-\mathrm{a} .2016 .103 .008$

\title{
The influence of a mycorrhizal vaccine on the biochemical properties of soil in the plantation of blueberry
}

\author{
Zofia ZYDLIK ${ }^{1}$, Eugeniusz PACHOLAK ${ }^{1}$, Krzysztof RUTKOWSKI ${ }^{1}$, Katarzyna STYŁA², \\ Piotr ZYDLIK ${ }^{1}$ \\ ${ }^{1}$ University of Life Sciences in Poznań \\ Dąbrowskiego 159, 60-594 Poznań, Poland \\ E-mail: zydlik@up.poznan.pl \\ ${ }^{2}$ Institute for Agricultural and Forest Environment Studies, Polish Academy of Sciences \\ Bukowska 19, 60-809 Poznań, Poland
}

\begin{abstract}
The studies were conducted at two sites (a replantation and a virgin soil site). The following two combinations were used for each of the sites: control with no treatments applied and with the application of a mycorrhizal vaccine on the root balls of the plants at the time of planting. The four-year research showed that the way of soil usage had an influence on its biochemical properties, which were evaluated on the basis of enzymatic activity, which, except for the dehydrogenases, was at a lower lever in the replanted soil site. The use of a mycorrhizal vaccine did not increase the enzymatic activity in the replanted soil site, sometimes even lowered it. The content of organic matter defined as the total content of carbon and dissolvable carbon in the soil was higher at the replanted site than at the virgin soil one. The use of the mycorrhizal vaccine contributed to the increase of the content of the organic matter but only in the virgin soil site. The soil from the plantation growing on the virgin soil was characterized by the highest content of proteolytic bacteria and the highest respiratory activity.
\end{abstract}

Key words: enzymatic activity, indole-3-acetic acid, mycorrhiza, Vaccinium corymbosum.

\section{Introduction}

The processes that take place in soil are determined by the activity of various groups of microorganisms, such as viruses, bacteria, actinobacteria, fungi and algae (Russel, 2005). Productivity of soil is a result of the activity of its microorganisms. This group of organisms take part in the process of organic matter decomposition and create complex symbiotic, rhizosphere and mycorrhizal systems. The activity of microorganisms of the rhizosphere is one of the main factors determining the growth and pathogen resistance of a plant (Smith, Read, 2008). Fruit cultivation is a specific kind of a monoculture which has a significant influence on the properties of soil, in which the most frequent occurrencies are allopathic compounds accumulation, changes in the composition of microflora, deterioration of the quality of humus and accumulation of a great number of phenolic acids (Styła, 2014).

A frequent phenomenon occurring in the process of fruit production, also including highbush blueberry, is soil fatigue resulting from the use of replantation - planting plants from the same species in grubbed-up areas (Zydlik, 2004). Under replantation conditions, productive soil properties may be considerably exacerbated, thus limiting plant growth (Pacholak et al., 2009). In plantations of blueberry the problem of replantation may occur. Poland is a leading producer of this species in Europe. Consumer demand for high quality and the appearance of new and more attractive blueberry cultivars result in frequent changes in the planted cultivars. Additionally, farms producing highbush blueberry are specialized, which makes it difficult to switch to a different crop.

An indicator of the changes occurring in the soil under the influence of natural and anthropogenic factors is enzymatic activity (Makoi, Ndakidemi, 2008). The most important role in the soil is played by enzymes belonging to oxidoreductases (dehydrogenases) and hydrolases (protease, urease, phosphatase). The sources of enzymes occurring in the soil are microorganisms, roots and their residues as well as specific soil flora (Russel, 2005). In soil, there are not only enzymes, but also active biological compounds, which have a significant influence on the development and functioning of plants. This group includes plant hormones, among which, auxins are deemed to be the most significant ones, including indole3-acetic acid (Szajdak et al., 2011).

As Corstanje and Reddy (2006) state, the respiratory and enzymatic activity of soil is a better way of determining its state than its physiochemical properties. 
Respiratory activity is often related to decomposition of organic compounds and their oxidation, accompanied by secretion of carbon dioxide.

Deterioration of soil properties is one of the most important stress factors for plants. The only way to prevent unfavourable soil conditions is to use of a mycorrhizal inoculum. According to Midgley et al. (2004) and Swarty et al. (2004), using an ericoid mycorrhiza allows for decreasing the stress resulting from an unfavourable soil $\mathrm{pH}$, lack of water or high salinity (Ortas, 2008). Under the influence of mycorrhization, some species of fruit trees or bushes or their rootstocks achieve better growth parameters (Raj, Sharma, 2009; Aka-Kacar et al., 2010). This also applies to highbush blueberry (Arriagada et al., 2012). Photosynthetic activity of plants also grows (Fan et al., 2008).

The aim of the studies was to evaluate the influence of the soil site and the use of a mycorrhizal vaccine on the growth of blueberry and biochemical properties of the soil during the first years after replantation.

\section{Materials and methods}

Studies were carried out in 2009-2012 in the Department of Pomology of the University of Life Sciences in Poznań, on the area of the Agricultural and Pomologycal Experimental Farm in Przybroda. The farm is situated in Wysoczyzna Wielkopolska, where proper Luvisol occur, which are formed from loams lying on boulder clay. The content of floatable fractions ranges from $17 \%$ to $20 \%$ and the $\mathrm{pH}$ is 5.4 .

The plantation was created in the spring of 2009 by planting biennial, plug seedlings of the blueberry (Vaccinium corymbosum L.) variety 'Bluecrop', with spacing of $2.5 \times 1.5 \mathrm{~m}\left(2667\right.$ shrubs ha $\left.^{-1}\right)$. During the research period, soil temperatures at the depth of 10 $\mathrm{cm}$ were quite even and they amounted to $11.5^{\circ} \mathrm{C}$ and during the growing season, they ranged from $19.7^{\circ} \mathrm{C}$ to $20.3^{\circ} \mathrm{C}$. In winter, soil temperatures at the depth of $10 \mathrm{~cm}$ did not go below $0^{\circ} \mathrm{C}$. The average monthly and the average annual air temperatures and the amount of precipitation did not significantly diverge from multi-year data. Organic mulch was used in the plantation in the form of coniferous sawdust, $20 \mathrm{~cm}$ thick, which was distributed after planting bushes along the rows. In this way, weed growth and water losses were reduced. Additionally, drip irrigation lines were distributed in each row of plants, which were used in water-deficiency periods. In the growing season, fertilization and plant protection treatments were compliant with the recommendations for highbush blueberry cultivation. In the experiment, two sites were used: 1) the first site consisted of an area on which blueberry had been cultivated for over 30 years and then was grubbed in the autumn of 2008 (the replantation site), 2) the second site was the virgin soil site. Virgin soil is soil that has not been used for growing fruit trees/bushes. Agricultural plants (rapeseed, cereals) were grown on it. Such soil was prepared for the cultivation of highbush blueberries (the optimal $\mathrm{pH}$ value and nutrient content).
The experiment consisted of four combinations, which were as follows: combination 1 - shrubs planted in the replanted soil in the place of grubbed up plants, combination 2 - as in combination 1 but with a onetime application of a mycorrhizal vaccine, combination 3 - shrubs planted in the virgin soil, combination 4 - as in combination 3 but with a one-time application of a mycorrhizal vaccine. Each combination was represented by 4 replications, 10 shrubs each. The vaccines were prepared in the Polish laboratory "Mycoflor" (Puławy, Poland), based on fungi isolated from roots of Vaccinium myrtillus L., V. vitis-idaea L. and Arctostaphylos uva-ursi L. that originated from Polish ecosystems. On a one-off basis, while the bushes were being planted, vaccine at a dose of $15 \mathrm{ml}$ per plant was applied onto the root ball. The inoculant contained a live mycorrhizal mycelium in a hydrated state in the form of gel suspension.

The evaluation of biochemical properties of soil covered an analysis of enzymatic activity of the soil (proteases, dehydrogenases, acid phosphatase), the content of carbon and indole-3-acetic acid (IAA), its respiratory activity and the number of proteolytic bacteria.

The soil needed for the biochemical analysis was collected at three dates. In spring, samples were collected in the middle of May, in summer - after the end of the intensive growth of shrubs and in autumn - after leaves were subject to decolouration. Protease activity was determined with the use of the spectrophotometric method according to Ladd and Butler (1972); the enzymatic activity was expressed in $\mathrm{mg}$ of tyrosine $\mathrm{h}^{-1}$ $\mathrm{kg}^{-1}$ of dry mass. Dehydrogenase activity was determined with the use of the colorimetric method according to Thalmann (1968), expressing its activity in $\mathrm{cm}^{3} \mathrm{H}_{2}$ $24 \mathrm{~h}^{-1} \mathrm{~kg}^{-1}$ of dry mass. Acid phosphatase was measured spectrophotometrically with the use of the Tabatabai and Bremner's (1969) method expressing its activity in $\mathrm{mg}$ of $\mathrm{p}$-nitrophenol $\mathrm{kg}^{-1} \mathrm{~h}^{-1}$ of dry mass.

Together with the determination of the enzymatic activity, the following soil properties were determined during the same terms: total organic carbon (TOC) content with the use of Tiurin's method - TOC in $\mathrm{g} \mathrm{kg}^{-1}$ (Mocek et al., 2006), hot water extractable organic carbon $\left(\mathrm{C}_{\mathrm{HWE}}\right)$ content $-\mathrm{C}_{\mathrm{HWE}}$ in $\mathrm{g} \mathrm{kg}^{-1}$ (Smolander, Kitunen, 2002), IAA content with the use of the fluorescent method - IAA in $\mathrm{mg} \mathrm{kg}^{-1}$ (Szajdak et al., 2011). Respiratory activity of the soil in the growing conditions was estimated on the basis of saturated carbon dioxide $\left(\mathrm{CO}_{2}\right)$ with the use of the absorption method - $\mathrm{CO}_{2}$ in $\mathrm{mg} \mathrm{kg}^{-1} 48 \mathrm{~h}^{-1}$ (Gołębiowska, Pędziwilk, 1984). The amount of proteolytic bacteria in fresh soil on selective media was determined by the method according to Rodina (1968), with the use of the plate count method, after 48 hours of incubation at a temperature of $21^{\circ} \mathrm{C}$.

The results obtained were subject to a statistical analysis. One and two-factor analyses of variance with the use of Duncan's test and the significance of differences were determined at the statistical significance level of $\alpha=0.05$. The results were described on the basis of an average result from the four vegetation periods between 2009-2012 years. 


\section{Results and discussion}

According to Bielińska et al. (2008) and Arriagada et al. (2012), the enzymatic activity of soil constitutes a good indicator of its fertility and productivity. Our studies showed that the way of using soil intended for blueberry plantation had an influence on its biochemical properties evaluated on the basis of its enzymatic activity. We found that the enzymatic activity of the soil from the place of grubbed up shrubs (Table 1) was lower. In this way, the opinion of Pacholak et al. (2009) about a considerable decrease in the biological activity of soil under replantation conditions is confirmed. The lowered dehydrogenases activity on the replanted site may be the result of its low fertility and may be one of the elements indicating to the soil's fatigue.

Table 1. Enzymatic activity in soil (average activity from the period between 2009-2012)

\begin{tabular}{lccc}
\hline \multicolumn{1}{c}{ Site } & $\begin{array}{c}\text { Protease } \\
\text { mg tyrosine } \mathrm{h}^{-1} \mathrm{~kg}^{-1} \\
\text { dry mass soil }\end{array}$ & $\begin{array}{c}\text { Dehydrogenase } \\
\mathrm{cm}^{3} \mathrm{H}_{2} 24 \mathrm{~h}^{-1} \mathrm{~kg}^{-1} \\
\text { dry mass soil }\end{array}$ & $\begin{array}{c}\text { Acid phosphatase } \\
\mathrm{mg} \mathrm{p}^{-n i t r o p h e n o l ~ k g} \mathrm{~h}^{-1} \\
\text { dry mass soil }\end{array}$ \\
\hline Replantation & $3.72 \mathrm{a}$ & $0.92 \mathrm{a}$ & $8.56 \mathrm{a}$ \\
Replantation + mycorrhyza & $4.22 \mathrm{ab}$ & $0.93 \mathrm{a}$ & $8.69 \mathrm{a}$ \\
Virgin soil & $3.94 \mathrm{a}$ & $1.18 \mathrm{~b}$ & $9.52 \mathrm{~b}$ \\
Virgin soil + mycorrhyza & $4.55 \mathrm{~b}$ & $1.42 \mathrm{c}$ & $10.87 \mathrm{c}$ \\
\hline
\end{tabular}

Note. Mean values marked with the same letter do not differ significantly at $\alpha=0.05$.

A one-time use of a mycorrhizal vaccine on the virgin soil during the period of planting shrubs contributed to a significant increase of the activity of each of the enzymes studied. This effect did not occur in the replanted site. The mycorrhizal vaccine did not increase the activity of each of the enzymes studied to a statistically significant extent. In this case, one of the reasons for the lack of effectiveness of the inoculant in increasing the enzymatic activity of replanted soil can be a low degree of root colonization by mycorrhizal fungi. This probably results from the accumulation of a range of compounds limiting the development of the soil microflora - phenolic acids, glycosides or allelopathic compounds (Benizri et al., 2005; Styla, 2014).

The enzymatic activity of the soil depended on the date of the sample collection. The highest protease activity was found in the spring season $(4.54 \mathrm{mg} \mathrm{mg}$ tyrosine $\mathrm{h}^{-1} \mathrm{~kg}^{-1}$ dry mass soil), and the lowest - during autumn (3.55 mg tyrosine $\mathrm{h}^{-1} \mathrm{~kg}^{-1}$ dry mass soil). The level of dehydrogenases activity was the highest in autumn (1.48 $\mathrm{cm}^{3} \mathrm{H}_{2} 24 \mathrm{~h}^{-1} \mathrm{~kg}^{-1}$ dry mass soil), and the lowest in summer $\left(0.61 \mathrm{~cm}^{3} \mathrm{H}_{2} 24 \mathrm{~h}^{-1} \mathrm{~kg}^{-1}\right.$ dry mass soil $)$, while acid phosphatase was the highest in summer $(10.62 \mathrm{mg}$ p-nitrophenol $\mathrm{kg}^{-1} \mathrm{~h}^{-1}$ dry mass soil), and the lowest in autumn (7.76 mg p-nitrophenol $\mathrm{kg}^{-1} \mathrm{~h}^{-1}$ dry mass soil). Higher activity of the enzyme in spring may have resulted from optimal soil temperatures during this period and its sufficient moisture content for microorganisms.

As it can be observed from data from literature (Acosta-Martinez et al., 2007; Chang et al., 2007), the enzymatic activity in the soil may depend not only on its type, but also on the content of organic matter. This thesis was not confirmed in these studies. The content of organic matter, estimated on the basis of the total carbon content and the content of dissolvable carbon was at a higher level at the replanted site than at the virgin soil site (Tables 2-3); while the enzymatic activity at this site was significantly lower (Table 1). A high content of organic matter in replanted soil may have resulted from insufficient numbers and activity of soil microorganisms, which translates into slower decomposition of organic substances.

The mycorrhizal vaccine increased the total content of organic and hot water extractable organic carbon in the soil; however, the effect was found only in the virgin soil. A statistical analysis did not indicate any significant differences between the content of total organic carbon and hot water extractable organic carbon after using the mycorrhizal vaccine at the replanted site (Tables 2-3). The date of sample collection indicated an influence on the total organic carbon content in the soil, which was the highest in summer, and the lowest in autumn (Table 2).

Table 2. Differences of the total organic carbon (TOC) content in the soil of the investigated sites (average content from the period between 2009-2012)

\begin{tabular}{|c|c|c|c|c|}
\hline \multirow{2}{*}{ Site } & \multicolumn{3}{|c|}{ TOC mg kg-1 } & \multirow{2}{*}{$\begin{array}{l}\text { Mean value } \\
\text { for site }\end{array}$} \\
\hline & spring & summer & autumn & \\
\hline Replantation & $12.85 \mathrm{~d}$ & $16.55 \mathrm{e}$ & $10.45 \mathrm{ab}$ & $13.28 \mathrm{~b}$ \\
\hline Replantation + mycorrhyza & $12.03 \mathrm{~cd}$ & $15.96 \mathrm{e}$ & $9.63 \mathrm{a}$ & $12.54 \mathrm{~b}$ \\
\hline Virgin soil & $10.56 \mathrm{ab}$ & $12.07 \mathrm{~cd}$ & $10.75 \mathrm{a}-\mathrm{c}$ & $11.13 \mathrm{a}$ \\
\hline Virgin soil + mycorrhyza & $11.51 \mathrm{~b}-\mathrm{d}$ & $15.63 \mathrm{e}$ & $12.38 \mathrm{~d}$ & $13.17 \mathrm{~b}$ \\
\hline Mean value for terms & $11.74 \mathrm{~b}$ & $15.05 \mathrm{c}$ & $10.80 \mathrm{a}$ & \\
\hline
\end{tabular}

Note. Mean values marked with the same letter do not differ significantly at $\alpha=0.05$. 
The content of hot water extractable organic carbon was the highest in spring, and the lowest in autumn (Table 3).

The statistical analysis results did not indicate an influence of the site on the content of IAA in the soil (Table 4). It must be stated that the use of the mycorrhizal vaccine during plantation did not have a significant effect on the change of the IAA content in the soil. The date of sample collection had an influence on the content of IAA. The highest content of IAA was found in the samples collected in spring, and the lowest - in autumn.

Table 3. The content of hot water extractable organic carbon $\left(\mathrm{C}_{\mathrm{HWE}}\right)$ in the soil of the investigated sites (average content from the period between 2009-2012)

\begin{tabular}{lcccc}
\hline \multirow{2}{*}{ Site } & \multicolumn{3}{c}{} & \multicolumn{2}{c}{$\begin{array}{c}\text { Mean value } \\
\text { for site }\end{array}$} \\
\cline { 2 - 4 } & spring & summer & autumn & $0.60 \mathrm{c}$ \\
Replantation & $0.65 \mathrm{e}$ & $0.58 \mathrm{~cd}$ & $0.58 \mathrm{~cd}$ & $0.59 \mathrm{bc}$ \\
Replantation + mycorrhyza & $0.61 \mathrm{de}$ & $0.63 \mathrm{e}$ & $0.52 \mathrm{~b}$ & $0.49 \mathrm{a}$ \\
Virgin soil & $0.55 \mathrm{~b}-\mathrm{d}$ & $0.47 \mathrm{a}$ & $0.46 \mathrm{a}$ & $0.57 \mathrm{~b}$ \\
Virgin soil + mycorrhyza & $0.55 \mathrm{bc}$ & $0.56 \mathrm{~b}-\mathrm{d}$ & $0.60 \mathrm{c}-\mathrm{e}$ & $0.54 \mathrm{a}$ \\
\multicolumn{1}{c}{ Mean value for terms } & $0.59 \mathrm{~b}$ & $0.56 \mathrm{a}$ & & \\
\hline
\end{tabular}

Note. Mean values marked with the same letter do not differ significantly at $\alpha=0.05$.

Table 4. The content of indole-3-acetic acid (IAA) in the soil of the investigated sites (average content from the period between 2009-2012)

\begin{tabular}{lcccc}
\hline \multicolumn{1}{c}{ Site } & \multicolumn{3}{c}{ IAA in mg kg-1 } & Mean value \\
& spring & summer & autumn & for site \\
\cline { 2 - 4 } & $92.72 \mathrm{c}$ & $94.15 \mathrm{c}$ & $55.98 \mathrm{a}$ & $80.95 \mathrm{a}$ \\
Replantation & $86.28 \mathrm{bc}$ & $91.51 \mathrm{c}$ & $49.27 \mathrm{a}$ & $75.69 \mathrm{a}$ \\
Replantation + mycorrhyza & $93.71 \mathrm{c}$ & $75.23 \mathrm{~b}$ & $55.17 \mathrm{a}$ & $74.70 \mathrm{a}$ \\
Virgin soil & $89.66 \mathrm{bc}$ & $84.91 \mathrm{bc}$ & $48.39 \mathrm{a}$ & $74.32 \mathrm{a}$ \\
Virgin soil + mycorrhyza & $90.59 \mathrm{~b}$ & $86.45 \mathrm{~b}$ & $52.21 \mathrm{a}$ & \\
\hline \multicolumn{1}{c}{ Mean value for terms } &
\end{tabular}

Note. Mean values marked with the same letter do not differ significantly at $\alpha=0.05$.

Respiration of plants is commonly seen as one of the main indicators of biological activity of soils, informing about, among others, a process of degradation or renovation of soil under the influence of various environmental factors.

The results obtained reveal a relation between the respiratory activity of the soil and the type of a site. The highest level of respiratory activity was found in the virgin soil $\left(152.9 \mathrm{CO}_{2}\right.$ in $\left.\mathrm{mg} \mathrm{kg}^{-1} 48 \mathrm{~h}^{-1}\right)$ and the lowest in the soil after replantation (126.3 $\mathrm{CO}_{2}$ in $\left.\mathrm{mg} \mathrm{kg}^{-1} 48 \mathrm{~h}^{-1}\right)$. The use of the mycorrhizal vaccine during plantation of shrubs in the virgin soil contributed to the decrease of the respiratory activity of the soil $\left(138.7 \mathrm{CO}_{2}\right.$ in $\mathrm{mg} \mathrm{kg}^{-1} 48$ $\mathrm{h}^{-1}$ ). The influence of environment on the soil respiratory activity was noticed also by Szafranek-Nakonieczna and Stępniewska (2014).

The respiratory activity of the soil may be related to, amongst other things, metabolic activity of some groups of microorganisms, including proteolytic bacteria. Their amount in the soil samples depended on the investigated site (Table 5).

Table 5. The number of proteolytic bacteria in the soil of the investigated sites (average number from the period between 2009-2012)

\begin{tabular}{|c|c|c|c|c|}
\hline \multirow{2}{*}{ Site } & \multicolumn{3}{|c|}{ Number in $1 \mathrm{~g}$ fresh mass soil $\times 10^{4}$} & \multirow{2}{*}{$\begin{array}{l}\text { Mean value } \\
\text { for site }\end{array}$} \\
\hline & spring & summer & autumn & \\
\hline Replantation & $1.60 \mathrm{a}$ & $8.80 \mathrm{~cd}$ & $1.60 \mathrm{a}$ & $4.00 \mathrm{a}$ \\
\hline Replantation + mycorrhyza & $4.00 \mathrm{~b}$ & $7.70 \mathrm{c}$ & $7.80 \mathrm{c}$ & $6.50 \mathrm{~b}$ \\
\hline Virgin soil & $15.80 \mathrm{e}$ & $20.30 \mathrm{f}$ & $9.10 \mathrm{~cd}$ & $15.07 \mathrm{c}$ \\
\hline Virgin soil + mycorrhyza & $7.00 \mathrm{c}$ & $4.20 \mathrm{~b}$ & $10.60 \mathrm{~d}$ & $7.27 \mathrm{~b}$ \\
\hline Mean value for terms & $7.10 \mathrm{a}$ & $10.25 \mathrm{~b}$ & $7.28 \mathrm{a}$ & \\
\hline
\end{tabular}

Note. Mean values marked with the same letter do not differ significantly at $\alpha=0.05$.

The lowest amount of the proteolytic bacteria was found in the replanted site, and the highest - in the soil from the plantation created on the virgin soil. The highest respiratory activity was also found in this site. The use of the mycorrhizal vaccine contributed to the increase of the number of proteolytic bacteria in the replanted soil, while in the case of the virgin soil, their number was reduced. The amount of proteolytic bacteria in the soil also depended on the sample collection date (Table 5). 


\section{Conclusions}

The research showed that:

1. The application of the mycorrhizal vaccine significantly increased the enzymatic activity of soil which had not been used for orchards before. No similar effect was obtained on replanted soil.

2. The mycorrhizal vaccine increased the total content of organic carbon, as well as the content of water extratable carbon in the virgin soil.

3. No significant influence of the soil site, and the mycorrhizal vaccine, on the indole-3-acetic acid (IAA) content in soil, was found.

4. The highest respiratory activity was found at the virgin sites, and the lowest at the site after replantation. No positive influence of the mycorrhizal vaccine on the increase of the respiratory activity of soil was shown.

5 . The number of proteolytic bacteria was the highest in the virgin soil, and the lowest in the replanted soil. The application of the mycorrhizal vaccine in the replanted soil contributed to the increase in the number of proteolityc bacteria.

\section{Acknowledgements}

The studies were partially funded in the scope of research project 44/2008/GW.

Received 15052015

Accepted 23092015

\section{References}

Acosta-Martinez V., Mikha M. M., Vigil M. F. 2007. Microbial communities and enzyme activities in soils under alternative crop rotations compared to wheat-fallow for the Central Great Plains. Applied Soil Ecology, 37: 41-52 http://dx.doi.org/10.1016/j.apsoil.2007.03.009

Aka-Kacar Y., Akpinar C., Agar A., Yalcin-Mendi Y., Serge S., Ortas I. 2010. The effect of mycorrhiza in nutrient uptake and biomass of cherry rootstocks during acclimatization. Romanian Biotechnological Letters, 15 (3): 5246-5252

Arriagada C., Manquel D., Cornejo P., Soto P., Sampedro I., Ocampo J. 2012. Effect of the co-inoculation with saprobe and mycorrhizal fungi on Vaccinium corymbosum growth and some soil enzymatic activities. Journal of Soil Science and Plant Nutrition, 12 (2): 283-294 http://dx.doi.org/10.4067/S0718-95162012000200008

Benizri E., Piutti S., Verger S., Pages L., Vercambre G., Poessel J. L., Michelot P. 2005. Replant diseases: bacterial community structure and diversity in peach rhizosphere as determined by metabolic and genetic fingerprinting. Soil Biology and Biochemistry, 37: 1738-1746 http://dx.doi.org/10.1016/j.soilbio.2005.02.009

Bielińska E. J., Futa B., Mocek A. 2008. The impact of agrotechnical operations on the functioning of agricultural landscape. Inżynieria Rolnicza, 10 (108): 7-15 (in Polish)

Chang E. H., Chung R. S., Tsai Y. H. 2007. Effect of different application rates of organic fertilizer on soil enzyme activity and microbial population. Soil Science and Plant Nutrition, 53: 132-140 http://dx.doi.org/10.1111/j.1747-0765.2007.00122.x
Corstanje R., Reddy K. R. 2006. Microbial indicators of nutrient enrichment. Soil Science of American Journal, 70: 1652-1661 http://dx.doi.org/10.2136/sssaj2004.0070

Fan Y., Luan Y., Yu K. 2008. Arbuscular mycorrhizae formed by Penicillium pinophilium improve the growth, nutrient uptake and photosynthesis of strawberry with two inoculumtypes. Biotechnology Letters, 30 (8): 1489-1494 http://dx.doi.org/10.1007/s10529-008-9691-8

Gołębiowska J., Pędziwilk Z. 1984. CO, release as on index of biological activity of cultivated soils. Acta Microbiologica Polonica, 33: 249-256

Ladd N., Butler J. H. A. 1972. Short-term assays of soil proteolytic enzyme activities using proteins and dipeptide derivatives as substrates. Soil Biology and Biochemistry, 4: $19-30$ http://dx.doi.org/10.1016/0038-0717(72)90038-7

Makoi J. H. J. R., Ndakidemi P. A. 2008. Selected soil enzymes: examples of their potential roles in the ecosystem. African Journal of Biotechnology, 7 (3): 181-191

Midgley D. J., Chambers S. M., Cairney W. G. 2004. Distribution of ericoid mycorrhizal entophytes and rootassociated fungi in neighbouring Ericaceae plants in the field. Plant and Soil, 259: 137-151 http://dx.doi.org/10.1023/B:PLSO.0000020947.13655.9f

Mocek A., Drzymała S., Maszner P. 2006. Genesis, analyses and classification of soil. Akademia Rolnicza Poznań (in Polish)

Ortas I. 2008. Field trials in mycorrhizal inoculation in the Eastern Mediterranean horticultural region. Feldman F. et al. (eds.). Mycorhhiza works. Hannover, Germany, 77 p.

Pacholak E., Zydlik Z., Rutkowski K. 2009. Effect of 30-year cultivation of apple trees on chemical and biochemical conditions of soil designed for replantation. Zeszyty Problemowe Postępów Nauk Rolniczych, 536: 161-168

Raj H., Sharma S. D. 2009. Integration of soil solarization and chemical sterilization with beneficial microorganisms for the control of white root and growth of nursery apple. Scientia Horticulturae, 119: 126-131 http://dx.doi.org/10.1016/j.scienta.2008.07.025

Rodina A. 1968. Microbiology methods of water studies. Warszawa, Poland (in Polish)

Russel S. 2005. The significance of studies of enzymes in soil environment. Acta Agrophysica, Rozprawy i Monografie, 3: 5-9

Smith S. E., Read D. J. 2008. Mycorrhizal symbiosis ( $3^{\text {rd }}$ ed). London, UK

Smolander A., Kitunen V. 2002. Soil microbial activities and characteristics of dissolved organic $\mathrm{C}$ and $\mathrm{N}$ in relation to tree species. Soil Biology and Biochemistry, 34: 651-660 http://dx.doi.org/10.1016/S0038-0717(01)00227-9

Styła K. 2014. Effect of long-term apple-tree cultivation and cultural practices in the orchard after replantation on the contents of indole-3-acetic acid and chemical compounds. Electronic Journal of Polish Agricultural Universities, 17 (3): 05

Swarty R. L., Decker T. R. J., Whitham T. G., Gehring C. A. 2004. Ectomycorrhizal abundance and community composition shifts with drought: predictions from tree rings. Ecology, 85: 1072-1084 http://dx.doi.org/10.1890/03-0224

Szafranek-Nakonieczna A., Stępniewska Z. 2014. Aerobic and anaerobic respiration in profiles of Polesie Lubelskie peatlands. International Agrophysics, 28 (4): 219-229 http://dx.doi.org/10.2478/intag-2014-0011 
Szajdak L. W., Gaca W., Meysner T., Styła K., Maryganova V. 2011. Enzymes activity and IAA contents in soils. Narwal S. S. et al. (eds.). Research methods in plant sciences. 2. Forestry and agroforestry. Houston, USA, $300 \mathrm{p}$.

Tabatabai M. A., Bremner J. M. 1969. Use of p-nitrophenyl phosphate for assay of soil phosphatase activity. Soil Biology and Biochemistry, 1: 301-307

http://dx.doi.org/10.1016/0038-0717(69)90012-1
Thalmann A. 1968. Zur Methodik der Bestimmung der Dehydrogenaseaktivität im Boden mittels Triphenyltetrazoliumchlorid (TTC). Landwirdschaft Forschung, 21: 249-258 (in German)

Zydlik Z. 2004. Effect of locality on the microbiological condition of soil from replanted apple orchard. Folia Universitatis Agriculturae Stetinensis, 96: 219-224

ISSN 1392-3196 / e-ISSN 2335-8947

Zemdirbyste-Agriculture, vol. 103, No. 1 (2016), p. 61-66

DOI 10.13080/z-a.2016.103.008

\title{
Mikorizès vakcinos įtaka dirvožemio biocheminėms savybėms šilauogių plantacijoje
}

\author{
Z. Zydlik ${ }^{1}$, E. PacholaK ${ }^{1}$, K. Rutkowski ${ }^{1}$, K. Styła ${ }^{2}$, P. Zydlik ${ }^{1}$ \\ ${ }^{1}$ Poznanès gyvybès mokslų universitetas, Lenkija \\ ${ }^{2}$ Lenkijos mokslų akademijos Žemès ūkio ir miško aplinkos tyrimų institutas
}

\section{Santrauka}

Tyrimas buvo atliktas dviejose vietose: dirvožemyje, kuriame prieš bandymą augo šilauogès, ir dirvožemyje, kuriame šilauogès nebuvo augintos. Abiejuose fonuose buvo naudoti kontroliniai variantai, kuriuose nebuvo taikyta jokių priemonių, ir variantai, kuriuose augalų šaknys sodinimo metu buvo apdorotos mikorizès vakcina. Ketverių metų tyrimų duomenys parodè, kad dirvožemio naudojimo būdas turèjo įtakos jo biocheminèms savybėms. Fermentų aktyvumas, išskyrus dehidrogenazès aktyvumą, buvo mažiausias dirvožemyje, kuriame augalai buvo atsodinti. Šiame dirvožemyje mikorizès vakcinos panaudojimas nepadidino fermentų aktyvumo, o kartais ji netgi mažino. Organinès medžiagos kiekis, apibrèžiamas kaip suminis anglies kiekis ir dirvoje ištirpusi anglis, buvo didesnis, kai augalai buvo atsodinti. Mikorizès vakcinos panaudojimas padidino organinès medžiagos kieki dirvožemyje, kuriame šilauogės nebuvo augintos. Didžiausias protelitinių bakterijų kiekis ir didžiausias respiracinis aktyvumas buvo nustatyti augalus auginant šiame dirvožemyje.

Reikšminiai žodžiai: fermentų aktyvumas, indolo-3-acetinè rūgštis, mikorizė, Vacccinium corymbosum.

Please use the following format when citing the article:

Zydlik Z., Pacholak E., Rutkowski K., Styła K. 2016. The influence of a mycorrhizal vaccine on a biochemical properties of soil in the plantation of blueberry. Zemdirbyste-Agriculture, 103 (1): 61-66 DOI 10.13080/z-a.2016.103.008 